Doi: HTTPS://DOI.ORG/10.23910/IJEP/2018.5.2.0237

\title{
Effects of Seed Pelleting on Seed Quality of Cowpea (Vigna unguiculata L.) During Storage
}

\author{
Nirmal Singh ${ }^{1 *}$, Ashok K. Thakur ${ }^{1}$, Rajesh Kaushal ${ }^{2}$, D. K. Mehta ${ }^{1}$ and Ramesh K. Bhardwaj ${ }^{3}$ \\ ${ }^{1}$ Dept. of Seed Science and Technology, ${ }^{2}$ Dept. of Soil Science and Water Management, ${ }^{3}$ Dept. of Vegetable Science, Dr. Yashwant \\ Singh Parmar University of Horticulture and Forestry, Nauni, Solan, H.P. (173 230), India
}

\section{Corresponding Author}

Nirmal Singh

e-mail: chaudhary100nu@gmail.com

\author{
Article History \\ Article ID: IJEP0237 \\ Received in $27^{\text {th }}$ January, 2018 \\ Received in revised form $7^{\text {th }}$ March, 2018 \\ Accepted in final form $25^{\text {th }}$ March, 2018
}

\begin{abstract}
An experiment was conducted during 2015-2016, to study the effects of seed pelleting on seed quality parameters of cowpea variety Himachal Lobia-1 during a storage period of one year. Seeds were checked for quality parameters at a monthly interval. Two formulations of Rhizobium viz-a-vis powder and liquid along with control (unpelleted) were used for experiment. The analysis of variance revealed that there were significant effects of seed pelleting and storage periods on germination, seedling length, seedling dry weight, seed vigour index-I and seed vigour index-II. Seeds pelleted with liquid formulation of Rhizobium gave maximum germination (93.55\%) whereas unpelleted seeds gave minimum germination (91.45\%) when seeds were germinated using between the paper methods. However, the germination decreased as the storage period increased. It ranged from $94.42 \%$ germination at 0 month to $89.52 \%$ at 12 months of storage. The interaction effects on germination due to seed pelleting and storage periods were found to be non-significant at $5 \%$ level of significance. Seed vigour index I was found to be maximum (2980.48) when fresh seeds were pelleted with liquid Rhizobium and minimum (2315.58) in unpelleted seeds stored for 12 months. Seed vigour index II also followed the same trend. It was found to be maximum (7451.34) in fresh seeds pelleted with liquid Rhizobium and minimum (6310.23) in unpelleted seeds stored for 12 months.
\end{abstract}

Keywords: Cowpea, quality, Rhizobium, seed pelleting

\section{Introduction}

Inoculation of legume seeds with Rhizobium spp. improves crop performance as it was demonstrated in laboratory and field experiments (O'Callaghan, 2016). Biological nitrogen fixation leads to significant reduction in production cost incurred on nitrogen fertilizers (Marcia et al., 2014). Seed pelleting of pulses with Rhizobium is yet another technology recommended for higher pulse yield. It ensures the buildup of sufficient bacterial population and to have the optimum symbiosis for enhanced crop productivity. Seed inoculation with arbuscular mycorrhizal fungi and nitrogen-fixing bacteria increased protein content in chickpea (Oliveira et al., 2017) and suppressed the root-infecting fungi in mungbean (Ramzan et al., 2016). Seed pelleting encloses the seed with the small quantity of filler material just large enough to produce the globular unit of standard size. The filler material creates natural water holding media and provides small amount of nutrient to young seedlings. Seed pelleting also serves as mechanism of applying needed material in such a way that they affect the seed or soil at the seed-soil interface. These materials can be nutrients, pesticides, growth regulators, biofertilizers etc. The seed pelleting focuses on better establishment and increased productivity by precision sowing and addition of various materials along with filler material that enhance the seed quality in many ways (Vanangamudi et al., 2010).

\section{Materials and Methods}

\subsection{Planting material}

The lab experiment was carried out at experimental laboratory of Department of Seed Science and Technology, Dr Y S Parmar University of Horticulture and Forestry, Nauni, Solan, HP (1250 $\mathrm{m}$ amsl) during April 2015-April 2016. Cowpea variety selected for lab trials was Himachal Lobia-1.

\subsection{Treatment details}

2.2.1. Factor 1: Rhizobium application: 03

(i) Control (unpelleted)

(ii) Rhizobium liquid formulation + clay + adhesive

(iii) Rhizobium powder formulation + clay + adhesive

\subsubsection{Factor 2: Storage period: 05}

(i) 0 month

(ii) 3 months

(iii) 6 months

(iv) 9 months 
(v) 12 months

Replications: 4

Design: CRD (factorial)

Seeds were stored under room temperature in plastic boxes. The data on temperature and relative humidity during storage in the laboratory is given in Appendix-l.

Germination (\%) was calculated as per the rules laid out by ISTA. Hundred seeds from all replications of each treatment were used for conducting the germination test. This was carried out by using paper roll method in the seed germinator at $25^{\circ} \mathrm{C}$. The first and final counts were taken after 7 and 14 days, respectively.

Germination (\%) was calculated by using the formula:

Germination(\%) $=\frac{\text { Number of normal seedlings }}{\text { Total number of seeds }} \times 100$

Seed vigour index-I (SVI-I) and seed vigour index-II (SVI-II) were calculated as per the formula given by Khare and Bhale (2000).

Seed vigour index-I (SVI-I) = Germination (\%) $\times$ Seedling length $(\mathrm{cm})$

Seedling vigour index-II (SVI-II) = Germination $(\%) \times$ Seedling dry weight (mg)

The statistical analysis for CRD (factorial) was done as per design of experiment as suggested by Gomez and Gomez (1984).

\section{Results and Discussion}

The analysis of variance revealed that there were significant effects of seed pelleting and storage periods on germination $\%$, seedling length, seedling dry weight, seed vigour index-I and seed vigour index-II.

\subsection{Germination (\%)}

The perusal of data presented in Table 1 indicated that different type of pelleting and different storage period had significant effects on germination. Among different types of pelleting, maximum germination (93.55\%) was found with Rhizobium culture pelleted seeds $\left(\mathrm{T}_{2}\right)$ and minimum $(91.45 \%)$ was found in unpelleted seeds $\left(T_{1}\right)$. Different storage period had also exhibited significant effects on germination. Maximum germination (94.42\%) was found at 0 month $\left(\mathrm{S}_{0}\right)$ which was at par with 3 months (93.75\%). However, minimum germination (89.58\%) was found at 12 months of storage $\left(\mathrm{S}_{12}\right)$. The interaction effects on germination due to seed pelleting and storage periods were found to be non-significant at $5 \%$ level of significance.

The growth promoting substance and nutrients present in the pelleting material helped for better seedling performance. Such beneficial influence of pelleting material in enhancing storability and seed quality was reported in cowpea (Maraddi, 2002), Bengal gram (Patil et al., 2002) and maize (Sharma, 1995). The enhancement in germination of seeds pelleted with Rhizobium might also be due to continuous supply of nutrients from pellet and increased cytokinin production which actively involved in cell division and production of growth regulating
Table 1: Effect of seed pelleting on seed germination during storage

\begin{tabular}{lcccccc}
\hline Treatments & \multicolumn{6}{c}{ Germination (\%) } \\
\cline { 2 - 7 } & \multicolumn{6}{c}{ Storage Duration (Months) } \\
\cline { 2 - 7 } & $\mathrm{S}_{0}$ & $\mathrm{~S}_{3}$ & $\mathrm{~S}_{6}$ & $\mathrm{~S}_{9}$ & $\mathrm{~S}_{12}$ & Mean \\
\hline $\mathrm{T}_{1}$ & 93.25 & 92.75 & 91.75 & 90.25 & 89.25 & 91.45 \\
& $(9.71)$ & $(9.68)$ & $(9.63)$ & $(9.55)$ & $(9.50)$ & $(9.61)$ \\
$\mathrm{T}_{2}$ & 96.00 & 95.00 & 94.50 & 92.25 & 90.00 & 93.55 \\
& $(9.85)$ & $(9.80)$ & $(9.77)$ & $(9.66)$ & $(9.54)$ & $(9.72)$ \\
$\mathrm{T}_{3}$ & 94.00 & 93.50 & 93.00 & 90.75 & 89.50 & 92.15 \\
& $(9.75)$ & $(9.72)$ & $(9.70)$ & $(9.58)$ & $(9.51)$ & $(9.65)$ \\
Mean & 94.42 & 93.75 & 93.08 & 91.08 & 89.58 \\
& $(9.77)$ & $(9.73)$ & $(9.70)$ & $(9.60)$ & $(9.51)$ &
\end{tabular}

Figures in parenthesis are square root transformed.

$\begin{array}{lccc}\text { Factor } & T & S & T \times S \\ \text { SEm } \pm & 0.01 & 0.01 & - \\ \mathrm{CD}(p=0.05) & 0.03 & 0.04 & \mathrm{NS}\end{array}$

$\mathrm{S}_{0}$ : (0 month); $\mathrm{S}_{3}:$ (3 months); $\mathrm{S}_{6}:$ (6 months); $\mathrm{S}_{9}$ : (9 months); $\mathrm{S}_{9}$ : (12 months); $\mathrm{T}_{1}$ : (Control); $\mathrm{T}_{2}$ : (Rhizobium culture pelleting); $\mathrm{T}_{3}$ : (Rhizobium powder pelleting);

substances like auxin, gibberellins and cytokinin. Similar findings have been reported in brinjal (Satish kumar et al., 2014) and chilli (Jerlin et al., 2008). The higher germination in fresh pelleted seeds as compared to old pelleted seeds is due to age of seeds because loss of germination ability depends upon the time span as also reported by Aquilla (1987). The major reason for loss in germinability of seeds stored at ambient conditions seems to be the DNA degradation in seeds during ageing or impaired transcription or lipid peroxidation in seeds (McDonald and Copeland, 1995).

\subsection{Seed vigour index-I}

The results on seed vigour index-I as influenced by seed pelleting and storage period are presented in Table 2. Maximum seed vigour index-I (2786.66) was found in Rhizobium culture pelleted seeds $\left(T_{2}\right)$ and minimum (2563.37) was found in the unpelleted seeds $\left(T_{1}\right)$.Storage period also influenced seed vigour index-I. Maximum seed vigour index-I (2869.07) was found in fresh pelleted seeds $\left(\mathrm{S}_{0}\right)$ and minimum seed vigour index-II (2471.99) was found at 12 months $\left(\mathrm{S}_{12}\right)$. The interaction effects due to seed pelleting and storage period were found to be significant at $5 \%$ level of significance. Maximum seed vigour index-I (2980.48) was found in $\mathrm{T}_{2} \mathrm{~S}_{0}$ (Rhizobium culture pelleting + 0 month) and minimum seed vigour index-I (2315.58) was found in $\mathrm{T}_{1} \mathrm{~S}_{12}$ (control + 12 months).

The enhanced seed vigour index-I of pelleted seeds might be due to higher germination and increased seedling length. The reduced seedling vigour might be due to decreased germination and seedling length with increasing age of seeds. 


\begin{tabular}{|c|c|c|c|c|c|c|}
\hline \multirow[t]{3}{*}{ Treatments } & \multicolumn{6}{|c|}{ Seed vigour index-I } \\
\hline & \multicolumn{6}{|c|}{ Storage duration (Months) } \\
\hline & $\begin{array}{c}\mathrm{S}_{0} \\
\text { (0 month) }\end{array}$ & $\begin{array}{c}\mathrm{S}_{3} \\
\text { (3 months) }\end{array}$ & $\begin{array}{c}\mathrm{S}_{6} \\
\text { (6 months) }\end{array}$ & $\begin{array}{c}\mathrm{S}_{9} \\
\text { (9 months) }\end{array}$ & $\begin{array}{c}\mathrm{S}_{12} \\
\text { (12 months) }\end{array}$ & Mean \\
\hline$T_{1}$ & 2792.70 & 2752.03 & 2571.60 & 2384.95 & 2315.58 & 2563.37 \\
\hline $\mathrm{T}_{2}$ & 2980.48 & 2947.25 & 2806.88 & 2640.38 & 2558.33 & 2786.66 \\
\hline $\mathrm{T}_{3}$ & 2834.03 & 2800.15 & 2682.68 & 2599.78 & 2542.08 & 2691.74 \\
\hline Mean & 2869.07 & 2833.14 & 2687.05 & 2541.70 & 2471.99 & \\
\hline Factor & \multicolumn{2}{|c|}{$\mathrm{T}$} & \multicolumn{2}{|c|}{$\mathrm{s}$} & \multicolumn{2}{|c|}{$T \times S$} \\
\hline SEm \pm & \multicolumn{2}{|c|}{13.61} & \multicolumn{2}{|c|}{17.57} & \multicolumn{2}{|c|}{30.45} \\
\hline $\mathrm{CD}(p=0.05)$ & \multicolumn{2}{|c|}{38.67} & \multicolumn{2}{|c|}{49.92} & \multicolumn{2}{|c|}{86.48} \\
\hline
\end{tabular}

The ageing or deterioration of seeds is a progressive process, which reduced germination capacity and growth of seedlings with increasing age (Floris, 1970).

\subsection{Seed vigour index-II}

The results on seed vigour index-II as influenced by different seed pelleting and storage periods are presented in Table 3. Maximum seed vigour index-II (6981.37) was found in Rhizobium culture pelleted seeds $\left(T_{2}\right)$ and minimum (6546.27) was found in the unpelleted seeds $\left(T_{1}\right)$. Storage period also influenced seed vigour index-II. Maximum seed vigour indexII (7130.85) was found at 0 month $\left(S_{0}\right)$ and minimum seed vigour index-II (6419.89) was found at 12 months $\left(S_{12}\right)$. The interaction effects due to seed pelleting and storage period were found to be significant at $5 \%$ level of significance. Maximum seed vigour index-II (7451.34) was found in $\mathrm{T}_{2} \mathrm{~S}_{0}$ (Rhizobium culture pelleting +0 month) and minimum seed vigour index-II (6310.23) was found in $\mathrm{T}_{1} \mathrm{~S}_{12}$ (control +12 months).

The enhanced seed vigour index-Il of pelleted was due to increased germination and seedling dry weight. The reduction in seedling vigour in old pelleted seeds was due to reduction in germination and seedling dry weight. The ageing or

Table 3: Effect of seed pelleting on seed vigour index-II during storage

\begin{tabular}{|c|c|c|c|c|c|c|}
\hline \multirow[t]{3}{*}{ Treatments } & \multicolumn{6}{|c|}{ Seed vigour index-II } \\
\hline & \multicolumn{6}{|c|}{ Storage Duration (Months) } \\
\hline & $\begin{array}{c}\mathrm{S}_{0} \\
\text { (0 month) }\end{array}$ & $\begin{array}{c}\mathrm{S}_{3} \\
\text { (3 months) }\end{array}$ & $\frac{\mathrm{S}_{6}}{\text { (6 months) }}$ & $\begin{array}{c}\mathrm{S}_{9} \\
\text { (9 months) }\end{array}$ & $\begin{array}{c}\mathrm{S}_{12} \\
\text { (12 months) }\end{array}$ & Mean \\
\hline $\mathrm{T}_{1}$ & 6765.67 & 6643.18 & 6566.47 & 6445.80 & 6310.23 & 6546.27 \\
\hline $\mathrm{T}_{2}$ & 7451.34 & 7116.85 & 7029.49 & 6773.02 & 6536.14 & 6981.37 \\
\hline $\mathrm{T}_{3}$ & 7175.53 & 6977.37 & 6806.71 & 6520.68 & 6413.30 & 6778.72 \\
\hline Mean & 7130.85 & 6912.46 & 6800.89 & 6579.83 & 6419.89 & \\
\hline Factor & \multicolumn{2}{|c|}{$\mathrm{T}$} & \multicolumn{2}{|c|}{$\mathrm{S}$} & \multicolumn{2}{|c|}{$\mathrm{T} \times \mathrm{S}$} \\
\hline SEm \pm & \multicolumn{2}{|c|}{23.53} & \multicolumn{2}{|c|}{30.38} & \multicolumn{2}{|c|}{52.63} \\
\hline $\operatorname{CD}(p=0.05)$ & \multicolumn{2}{|c|}{66.84} & \multicolumn{2}{|c|}{86.29} & \multicolumn{2}{|c|}{149.47} \\
\hline
\end{tabular}

deterioration of seeds is a progressive process, which reduced germination capacity and growth of seedlings with increasing age (Floris, 1970).

\section{Conclusion}

Seed pelleting is found to be a proven method to improve cowpea germination. Pelleting of fresh seeds with Rhizobium liquid culture improves seed quality parameters considerably.

\section{References}

Aquilla, A.D., 1987. Mean germination time as a monitor of the seed ageing. Plant Physiology Biochemistry 25, 761-768. Floris, C., 1970. Ageing in Triticum durum seeds: Behaviour of embryos and endosperms from aged seeds as revealed by the embryo-transplantation technique. Journal of Experimental Botany 21, 462-468.

Gomez, K.A., Gomez, A.A., 1984. Statistical Procedures for Agricultural Research. John Willy and Sons, New York, 690.

Jerlin, R., Ponnuswamy, A.S., Prabakhar, K., Srinivasan, M.R., 2008. Seed pelletization for enhancing seed vigour and storability of chillies cv. K 1. Madras Agricultural Journal 
$95,486-490$.

Kumar, S., Gowda, B., Kumar, S., 2014. Effect of seed pelleting chemicals and storage containers on storability of brinjal (Solanum melongena L.). International Journal of Plant Sciences 9: 173-179.

Maraddi, B., 2002. Influence of growth regulators on seed yield and quality and seed treatments on storability of cowpea cv. C-252, M. Sc. (Agriculture) thesis, University of Agriculture Science, Dharward, 216.

Marcia, R., Soares, B.L., Ferreira, P.A.A., Moreira, F.M.D.S., 2014. Cowpea symbiotic efficiency, $\mathrm{pH}$ and aluminium tolerance in nitrogen-fixing bacteria. Scientia Agricola $71,12-16$.

McDonald, M.B., Copeland, L.O., 1995. Principles of Seed Science and Technology. $3^{\text {rd }}$ edition. Chapman and Hall, 258-276.

O'Callaghan, M., 2016. Microbial inoculation of seed for improved crop performance: issues and opportunities. Applied Microbiology and Biotechnology 100, 57295746.

Oliveira, R.S., Carvalho, P., Marques, G., Ferreira, L., Nunes, M., Rocha, I., Ma, Y., Carvalho, M. F., Vosatka, M., Freitas,
H., 2017. Increased protein content of chickpea (Cicer arietinum L.) inoculated with arbuscular mycorrhizal fungi and nitrogen-fixing bacteria under water deficit conditions. Journal of the Science of Food and Agriculture 97, 4379-4385.

Patil, R.J., Dudhade, D.O., Patil, J.V., 2002. Response of chickpea to phosphorus under varying moisture regime. Agriculture Science 22, 130-131

Ramzan, N., Noreen, N., Perveen, Z., Shahzad, S., 2016. Effect of seed pelleting with biocontrol agents on growth and colonisation of roots of mungbean by root-infecting fungi. Journal of the Science of Food and Agriculture 96, 3694-3700.

Sharma, R.K., 1995. Neem leaf powder and cob ash against Rhyzopertha dominica (F.) in stored maize. Indian Journal of Entomology 57, 15-17.

Vanangamudi, G., Thirunarayanan, G., Surya, S., Srinivasan, S., Sathiyendiran, V., 2010. Synthetic and insect antifeedent activities of substituted styryl 3,4-dichlorophenyl ketones. Acta Spectrochimica 75, 152-15. 